\title{
Professionalism in the teaching of the elderly health care during nursing graduation
}

\author{
Profissionalismo no ensino do cuidado à saúde do idoso na graduação em enfermagem
}

João Paulo Xavier Silva ${ }^{1}$, Nayara Santana Brito ${ }^{1}$, Thiáskara Ramile Caldas Leite ${ }^{1}$, Evanira Rodrigues Maia ${ }^{1}$, Maria de Fátima Antero Sousa Machado ${ }^{1}$, Maria do Socorro Vieira Lopes ${ }^{1}$

Objective: to understand the attributes formulation for the professionalism education in the teaching of the elderly health care during the nursing graduation. Methods: this is a qualitative study carried out in four educational institutions to evaluate educational planning documents of the elderly health subject. The lexical type content analysis was used through the Lexical Contextual Analysis software of a Set of Text Segments. Results: two discursive classes emerged: Perspective for theoretical-practical learning and Content-based teaching. The categories show an educational model anchored in the transmission of content with little emphasis on teaching by competence and training of skills essential for the development of the nurse professional identity in the elderly's health. Conclusion: in the educational planning documents, it is not possible to observe the attributes for the professionalism education in the formation of an identity profile in a clear and structured way focused on the elderly's health.

Descriptors: Nursing; Health of the Elderly; Professionalism.

Objetivo: compreender a formulação de atributos para a formação de profissionalismo no ensino do cuidado à saúde do idoso na graduação em enfermagem. Métodos: estudo qualitativo realizado em quatro instituições de ensino para avaliar documentos de planejamento educacional da disciplina saúde do idoso. Foi utilizada a análise de conteúdo, do tipo lexical, por meio do software Análise Lexical Contextual de um Conjunto de Segmentos de Texto. Resultados: emergiram duas classes discursivas: Perspectiva para aprendizagem teórico-prática e Ensino baseado em conteúdo. As categorias evidenciam um modelo educacional ancorado na transmissão de conteúdos com pouca ênfase no ensino por competências e formação de habilidades fundamentais para o desenvolvimento da identidade profissional do/a enfermeiro/a na saúde do idoso. Conclusão: nos documentos de planejamento educacional não é possível observar de maneira clara e estruturada os atributos para o desenvolvimento de profissionalismo na formação de um perfil identitário voltado à saúde do idoso.

Descritores: Enfermagem; Saúde do Idoso; Profissionalismo.

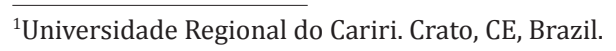




\section{Introduction}

Reflecting on the process of teaching learning and pedagogical practices in the nursing education area of the Brazilian Higher Education Institutions is an imperative necessity. The current educational scenario of health courses suggests the reproduction of the Flexnerian biomedical model, which makes it essential to effectively change students and teachers in the area and, more specifically, in nursing ${ }^{(1)}$.

Health education is moving towards a new horizon, in which two points are essential to provide qualified training: the integrated curriculum and continuing education. In integrated curriculum, the articulation between work, teaching, practice, theory, and community is found. In the continuing education, the educational process is linked to daily work, which must be constantly analyzed ${ }^{(2)}$.

In the academic context, discussions on the professionalism in the scope of renewal of teaching and practice in health have also gained considerable ground. The term refers to a set of interrelated skills for the benefit of the individual and the community. In nurses' education, the perspective of the identity profile assumes a fundamental character based on the construction and consolidation of knowledge, skills, and attitudes that conform to an ideal profile oriented to professional identity ${ }^{(3-4)}$.

The performance of the nursing professional at all levels of health care fosters a magnitude of care that must permeate several scenarios and consolidate in health promotion practices, including in the context of population aging, which should be conducive to the construction of an identity profile.

Considering the demographic and health transition of the population, the qualified attendance and the formation of human resources oriented to the health practices before the aging are demanded. However, the structured approach to care is absent in nursing curricula, formulated in a traditional way, without demonstrating advances in the area of profes- sionalism and requiring the development of specific competencies of the nurse for this purpose $\mathrm{e}^{(5-6)}$.

It is essential to research on the development of professionalism in nursing in the context of the health of the elderly, recognizing that in health training, aging must be seen in a broader perspective than strictly biological. The analysis and discussion of the curricula regarding the professionalism education in the undergraduate nursing courses are aspects of considerable relevance in the contemporary educational process.

Thus, there are questions that surround the nurse's training process in the health care provided to the elderly population. The question is: How is the nursing student's teaching process formulated on the identity profile? Do the educational planning documents of the undergraduate courses contain the necessary attributes for the professionalism education in nursing care for the elderly people? In this study, the objective was to understand the formulation of attributes for the education of professionalism in the teaching of health care of the elderly in nursing graduation.

\section{Methods}

This is a qualitative study for the evaluation of the educational planning documents of the elderly health subject during the nursing undergraduate courses. It was carried out in April and May of 2016 in four Higher Education Institutions located in the metropolitan region of Cariri, Ceará, Brazil.

The following items were analyzed to identify the formulation of contributory attributes for the education of professionalism in nursing documents; menus; general and specific objectives; content; skills; teaching methodologies; resources available at the university; and evaluation strategies and criteria.

The content analysis of the lexical type was carried out using the Lexical Contextual Analysis software of a Set of Text Segments (ALCESTE - Version 
2012), which investigates the distribution of vocabularies of the text, performing a lexical analysis of words automatically, by quantitative techniques, and the chi-square test $\left(\mathrm{khi}^{2}\right)$ stands out. The program works through the domain of the Descending Hierarchical Classification, which calculates the co-occurrences of words in text segments, grouping the semantic roots and defining them into classes ${ }^{(7)}$.

The texts of the educational planning documents were organized, typed in the Microsoft Word $\AA$ program and saved in the rich text format, constituting a unique database emerging the corpus entitled "Elderly". For analysis, the variables were as follows: Teaching institution (TI); competence (CP), which correspond to the general and specific objectives; contents (CT); strategies (ST), related to teaching and evaluation methodologies; and resources (RC). Each command line presented the variables of the institutions surveyed, which corresponds to the Initial Context Units for a total of four.

The study complied with the formal requirements contained in the national and international regulatory standards for research involving human beings.

\section{Results}

Documents from all institutions with undergraduate nursing courses in the study region were collected, one from the state public network and three from private education.

The software processed the analysis set that resulted in a $65.0 \%$ use of the material and pointed to two discursive classes. Each one covered specific semantic contexts and they were named with the following titles: Class 1 - Perspective for theoretical-practical learning and Class 2 - Content-based teaching. The denomination was based on the interpretation of the words corresponding to the class, as well as their meaning and the element of the educational planning document was found.

\section{Class 1 - Perspective for theoretical-practical learning}

Class 1 represents $66.0 \%$ of the classified words, consisting of 28 units and the relationship between "practice", "client", "subject", "evaluation" and "need". The contents of the educational planning documents that contributed to the formation of the class were the menu, the general and specific objectives and the evaluation process. The following clippings were selected by the software as the most representative of this class: The general objectives are to enable the student to effectively exercise activities aimed at clinical practice in nursing, perform theoretical nursing practice activities from the affected needs of the client applying theoretical knowledge about the basic nursing instruments that support the practice and base the exercise of the profession (Institution of Higher Education 1). This study aims to study the aging process by focusing on the biopsychosocial aspects aimed at the nursing care to the client in the elderly, the role of nursing in the care of the elderly (Institution of Higher Education 2).

Although Class 1 announces the conformity of the subjects analyzed with theoretical-practical teaching, which presupposes one of the elements of competency education, the documents do not provide textual evidence of the competences formulated for care in aging. The teaching strategies are traditional and the evaluation process is based, purely, on the summative type.

\section{Class 2 - Content-based teaching}

Class 2, consisting of 14 units, represents $34.0 \%$ of the words of classified text and presents its semantic sense around the words "aging", "main", "medicines", "second unit", "first unit", "Nursing" and "gerontology". The information that contributed to the formation of the class was the methodologies, the teaching strategies and the contents of the discipline. The following text represented the meaning of Class 2: Fourth unit: Health promotion and disease prevention in the elderly; continued care of the elderly; self-responsibility; morbidity and mor- 
tality; health promotion and disease prevention programs; strategies, recommendations and prevention of falls. Fifth unit: National policy of the elderly; health promotion policy for the elderly; home care; formal and informal social support networks (Institution of Higher Education 3).

The Class 2 training presents the contents of the subjects that are divided into a large number of units that must be addressed during the classes and ranged from five to 11 units, demonstrating strongly theoretical and content-based teaching.

\section{Discussion}

This study had limitations regarding professionalism because it is a multifaceted concept, with difficult evaluation and recently introduced in the theoretical discussions and research in nursing education. Also, the data were collected in a single metropolitan region of the State.

It was evidenced the difficulty of the educational institutions in determining the professional profile of the nurses who will work in the care of the elderly, which affects the approach of professionalism in the course of the subjects. Besides to content-centric teaching, the lack of definition of skills and abilities that determine a professional identity is detected.

The professional competences defined by the National Curricular Guidelines are fundamental guidelines for the construction of pedagogical projects and curricular matrices, as they guide the training of professionals to support the formulation of educational curricula to accompany work processes that are constantly changing ${ }^{(6)}$.

In the last decade, undergraduate nursing courses were stimulated to rethink the training models that (re) produce. The teaching standards adopted value the technical characteristics, to the detriment of the didactic-pedagogical aspects of individual and collective care, management/administration, decision making, leadership, permanent education, communication and relational issues, necessary for the professional profile of the nurse $\mathrm{e}^{(8)}$.
The identity of a profession evolves according to its history, by the choices and meanings attributed to its insertion in social contexts ${ }^{(8)}$. The identity profile comes from a dynamic construction in which the relational and biographical processes of the subject are included ${ }^{(9)}$.

It is essential to incorporate innovative actions that influence the identity of the nurse to follow the conceptual redefinitions of health and professional practice, so the knowledge and skills meet the health needs of the population. Besides to these characteristics, the nurse must be autonomous, independent and able to solve possible problems ${ }^{(10)}$.

The formation of Class 1 - Perspective for theoretical and practical learning, evidenced that the subjects of the health of the elderly in the Institutions of Higher Education studied are directed to the theoretical-practical teaching and directed to the basic human needs of the elderly patient, occurring privilege of content to the detriment of practical activities. The theoretical-practical subjects have great relevance in the academic education since they have the potential to develop skills and critical sense in the individual, inserting him closer to the professional reality ${ }^{(11)}$.

Regarding the use of Nursing Care Systematization, the analyzed documents show that only one institution points out its use during the activities of the subject. In the others, there is no explicit mention of the use of this instrument, evidencing gaps regarding the teaching of Nursing care. Despite the proposal and legal determination, the application of the Nursing Process in the daily practice of Brazilian health institutions does not materialize, which makes nursing assistance fragile ${ }^{(12)}$.

The Systematization of Nursing Care must occur through the adoption of some Nursing theory that scientifically bases the practices. In Brazil, there is a trend towards the applicability of the Nursing Process based on Wanda Aguiar Horta's Theory of Basic Human Needs to be based on self-care, recovery, maintenance, and promotion of the individual's health ${ }^{(13)}$.

Regarding the evaluation processes applied by 
the institutions, the summative predominates. Written tests and practical activities are used to verify student performance at specific times in the subjects. It should be noted that for the adequate accompaniment of the teaching-learning process of the students, they should be evaluated through the diagnostic, formative and summative modalities throughout the educational pathway ${ }^{(14)}$.

On the evaluative process, teachers should be trained to propose learning scenarios and appropriate assessment modalities to associate evaluation strategies and instruments that give meaning to their professional practice ${ }^{(15)}$.

The documents analyzed showed the interest of the institutions in discussing the actions of the nurse in the aging process. However, no specific learning objectives were found that directed the competency to be achieved, the teaching methodology and the evaluation modality to be implemented, distancing them from the established by the National Curricular Guidelines.

The discussion of nurses' professional competences for elderly health is already underway in the country. Researchers from the South region have developed a set of professional competencies to care for the elderly, leaving evident domains such as ethics, critical thinking, communication, health promotion, healthcare technologies and health information, among others. These competences are comprehensive and specific for decision-making, very relevant to the practical action and they are in line with the assumptions established in the National Curricular Guidelines ${ }^{(16)}$.

The clear establishment of competencies allows delineating the teaching on the health of the elderly, to the point of allowing the revision of curricula and the mobilization of students in the development of situations according to the demands pointed out and also contribute to the creation of strategies of education through general education ${ }^{(6)}$.

Class 2 - Content-based teaching strongly at- tributes for the development of competences related to the aging process, addressing anatomy, physiology and pathology contents, as well as public policies directed to the elderly from the health promotion to healing/rehabilitation.

The importance given to the content can be related to the current demographic and epidemiological profile that present an increasing number of elderly patients in health services. Therefore, it is necessary to train professionals who have the skills and competencies to develop health promotion, prevention and rehabilitation actions with quality. Class 2 consists exclusively of content units that reinforce the discussion in Class 1 about teaching being strongly based on theoretical content.

An integrative review study on the training of nursing students in elderly care shows that teaching and learning activities are predominantly practical in scenarios such as hospitals, health units, long-term institutions, and homes. These areas of practice are opportune for students to have an early approach to the life and health reality of the elderly population and to delineate care for a more effective and integral care $^{(6)}$

For the training of health professionals, the relevance of the acquired knowledge and the timely accomplishment of practical activities during the learning process are undeniable. The introduction of constructs related to professionalism can contribute to the quality of care and relationship in customer service $^{(17)}$. Since it is a set of obligations, attitudes, and behaviors of professionals should be applied in relationships with patients and the community as a who$\mathrm{le}^{(18)}$.

Professionalism involves fundamental attributes in the cognitive, attitudinal and psychomotor dimensions. Each of these dimensions has qualities and/or expectations that must be demonstrated. In the cognitive aspects, the basic understanding of the principles of the profession must be manifested. At- 
titudinal items are related to autonomy, competence, cooperation and social participation. And the psychomotor perspective presents the involvement of the professional in the therapeutic assistance from their personal qualifications ${ }^{(3)}$.

The findings of the study allowed verifying the need for the studied institutions to review nurses' training in elderly care to acquire the identity profile, so the curricula allow health teaching practices that relate individuals/communities to students and should be sensitized to the humanistic and technical attitudes that permeate the development of professionalism and social responsibility ${ }^{(17)}$.

In the analyzed documents, professionalism is tangential in the teaching-learning process, but a profile is not proposed that identifies the nursing student with his/her role with the elderly person in the training offered. The professional identity worked is a generalist, characterized by changeable character and restructuring according to established socialization processes and still finds negative aspects such as the non-recognition and visibility of the profession.

The lack of definition of the identity profile may be associated with the fact that Nursing is a science under construction that despite having a well-established theoretical foundation, it still needs to better define its object of study, Nursing care, through the results of its investigations ${ }^{(19)}$.

The analysis of publications in international databases identified, predominantly in Asian countries, negative factors that impede the adoption of a professional identity in Nursing, emphasized in the differences between the levels of education of nursing professionals, the hierarchical structure of hospitals, the burden of intense work, lack of equipment and equipment, insufficient job security, fragility of professional organizations, among others. Professionals must have good communication, achieve shared goals and provide care that guarantees patient safety and quality of care to achieve high levels of professionalism $^{(10)}$.

In the same study, the authors concluded that professionalism should be evaluated as a competence of future professionals and pointed out that research to determine the level of professionalism should be developed in regions without such data, such as Latin America $^{(10)}$.

For the teaching to meet the demands of an exponentially aging population and the development of attributes compatible with competence-based education, it is necessary to permanently review the curricula adopted by Higher Education Institutions. There is also an urgent need for the construction of an identity profile for qualified attention to the elderly, something incipient both in the formulation of the curricula and in the current scientific production.

It is suggested that the educational planning documents of the Higher Education Institutions be reformulated so they comply with the recommendations of the National Curricular Guidelines and favor the nurses' training process, using learning-teaching strategies that provide the development of skills based on professionalism.

\section{Conclusion}

In the educational planning documents analyzed in this study, it was not possible to observe in a clear and structured way the attributes for the development of professionalism in the formation of an identity profile of the nurse directed to the health of the elderly, since they have models of content subjects, with important quantity of theoretical classes and exclusively summative evaluations.

Curricula with a traditional structure that do not contemplate the guidelines of the National Curricular Guidelines and the particularities in the biopsychosocial contexts presented by the National Health Policy of the Elderly are highlighted. 


\section{Collaborations}

Silva JPX, Brito NS and Leite TRC contributed in the design and project, analysis and interpretation of the data, writing and final approval of the article. Maia ER contributed to the writing of the article, relevant critical review of the intellectual content and final approval of the article. Machado MFAS and Lopes MSV contributed in the design and project and approval of the final version to be published.

\section{References}

1. Lessmann JC, Lanzoni GMM, Gubert E, Mendes, PXG, Prado ML, Backes VM. Educação profissional em enfermagem: necessidades, desafios e rumos. Rev Min Enferm. 2012; 16(1):106-10. doi: http:// www.dx.doi.org/S1415-27622012000100015

2. Braid LMC, Machado MFAS, Aranha AC. Estado da arte das pesquisas sobre currículo em cursos de formação de profissionais da área da saúde: um levantamento a partir de artigos publicados entre 2005 e 2011. Interface Comunic Saúde Educ. 2012; 16(42):679-92. doi: http://dx.doi.org/10.1590/ S1414-32832012000300008

3. Ghadirian F, Salsali M, Cheraghi MA. Nursing professionalism: an evolutionary concept analysis. Iran J Nurs Midwifery Res [Internet]. 2014 [cited 2017 Aug 15]; 19(1):1-10. Available from: https://www.ncbi.nlm.nih.gov/pmc/articles/ PMC3917177/

4. Mendonça ET, Cotta RMM, Lelis VP, Carvalho Junior, PM. Assessment of professionalism in students of health-related courses: a systematic review. Interface. 2016; 20(58):679-90. doi: http:// dx.doi.org/10.1590/1807-57622015.0274.

5. Dias KCCO, Lopes MEL, Zaccara AAL, Duarte MCS, Morais GSN, Vasconcelos MF. Nursing care directed for the elderly: integrative review. Rev Enferm UFPE on line [Internet]. 2014 [cited 2017 Aug 15]; 8(5):1337-46. Available from: http:// www.revista.ufpe.br/revistaenfermagem/index. php/revista/article/viewArticle/5500
6. Perez CFA, Tourinho FSV, Carvalho Junior PM. Competencies in the nurse education process to care for the aging: an integrative review. Texto Contexto Enferm. 2016; 25(4):e0300015. doi:http://dx.doi.org/10.1590/010407072016000300015

7. Azevedo DM, Costa RKS, Miranda FAN. Use of the ALCESTE in the analysis of qualitative data: contributions to researches in nursing. Rev Enferm UFPE on line [Internet]. 2013[cited 2017 Aug 15]; 27(7):5015-22. Available from: http:// www.revista.ufpe.br/revistaenfermagem/index. php/revista/article/view/3297

8. Braga MJG. Ser professor: um estudo sobre a constituição identitária profissional do enfermeiro docente. Cad Educ [Internet]. 2013 [citado 2016 out 12]; 13(25):98-117. Disponível em:https: / / www.metodista.br/revistas / revistasims/index.php/cadernosdeeducacao/ article/view/4962/4167

9. Souza VLT. A constituição identitária do professor de psicologia: quem forma o formador? Psicol Ensino Form [Internet]. 2014 [citado 2017 jul 15]; 5(1):64-82. Disponível em: http://pepsic.bvsalud. org/pdf/pef/v5n1/v5n1a06.pdf

10. Luengo-Martínez C, Paravic-Klijn T, BurgosMoreno M. Profesionalismo en enfermería: una revisión de la literatura. Enferm Univ. 2017; 14(2):131-142. doi: http://dx.doi.org/10.1016/j. reu.2017.02.001

11. Freitas TLL, Madureira VSF, Maestri E. Relato de experiência acerca do ensino teórico-prático em atenção básica de saúde. Rev Enferm [Internet]. 2014 [citado 2016 out 15]; 10(10):4753. Disponível em: http://revistas.fw.uri.br/ index.php/revistadeenfermagem/article / view/1363/1848.

12. Medeiros AL, Santos SR, Cabral RWL. Revealing operational difficulties in the systematization of nursing care from the Grounded Theory perspective. Rev Eletr Enf. 2013; 15(1):44-53. doi: https://doi.org/10.5216/ree.v15i1.15323 
13. Leite MCA, Medeiros AL, Nóbrega MML, Fernandes MGM. Nursing care postpartum women using the Horta's Theory and INCP®. Rev Rene [Internet]. 2013 [cited 2017 set 15]; 14(1):199-208. Available from: http://www.revistarene.ufc.br/ revista/index.php/revista/article/view/1339/ pdf_1

14. Paiano LAG, Rodrigues RM, Conterno SRF, Camboin FF. Avaliação em estágio curricular na graduação em enfermagem: experiências e dificuldades vivenciadas por docentes. Educ Educare [Internet]. 2015 [citado 2016 out 15]; 10(esp):369-80. Disponível em: http://e-revista. unioeste.br/index.php/educereeteducare / article/view/9583/8584

15. Silva DSG, Matos PMS, Almeida DM. Métodos avaliativos no processo de ensino e aprendizagem: uma revisão. Cad Educ [Internet]. 2014 [citado 2017 may 27]; 47(1):73-84. Disponível em: https://periodicos.ufpel.edu.br/ojs2/index.php/ caduc/article/view/4651

16. Witt RR, Roos MO, Carvaho NM, Silva AM, Rodrigues CDS, Santos MT. Professional competencies in primary health care for attending to older adults. Rev Esc Enferm USP. 2014; 48(6):10201025. doi: http://dx.doi.org/10.1590/s0080623420140000700009
17. Benedetto MAC, Blasco PG, Gallian DMC. Medical and Nursing students' narratives: what have we learned? Rev Bras Med [Internet]. 2013 [cited 2017 Jul 27]; 70(3):11-7. Avaliable from: http://www. moreirajr.com.br $/$ revistas.asp?fase $=$ r003\&id materia $=5532$

18. Fantahun A, Demissie A, Gebrekirstos KK, Zemene A, Yetayeh G. A cross sectional study on factors influencing professionalism in nursing among nurses in Mekelle Public Hospitals, North Ethiopia, 2012. BMC Nurs. 2012; 13(1):1-7. doi: https://doi.org/10.1186/1472-6955-13-10

19. Van der Sand ICP, Hildebrandt LM, Cabral FB, Moreira MC, Gutiérrez MGR. Knowledge production in nursing in the light of societal fields and the quadripolar space of the research: a reflective exercise. Texto Contexto Enferm. 2013; 22(4):1187-96. doi: http://dx.doi.org/10.1590/ S0104-07072013000400038 